\title{
Influence of clinical and biological variants of premature aging on cognitive functionality
}

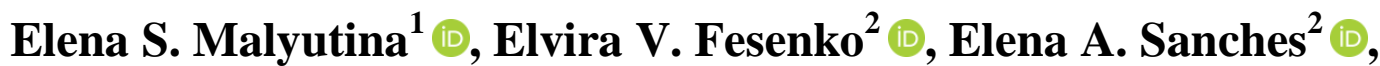 \\ Viktoriya D. Ismanova ${ }^{2}$, Oleg M. Kuzminov $^{1}{ }^{\circledR}$ \\ ${ }^{1}$ Belgorod State National Research University, \\ 85 Pobedy St., Belgorod, 308015, Russia \\ ${ }^{2}$ Academy of Postgraduate Education, Federal Scientific and Clinical Center for Specialized \\ Medical Assistance and Medical Technologies, Federal Medical Biological Agency, \\ 91 Volokolamskoe Highway, Moscow, 125371, Russia \\ Corresponding author: Elvira V. Fesenko(longtermcare.fmba@gmail.com)
}

\begin{abstract}
Background: Currently, the development of gerontology as a related medical and biological discipline follows the path of concepts; there are three of them in classical gerontology: frailty, intrinsic capacity and resilience, and in preventive medicine one - premature aging. The aim of the study: To study the features of cognitive functioning of people with various clinical and biological variants of premature aging. At the same time, insufficient attention is paid to cognitive and psychological functionality, which is largely the basis for the formation of resilience. Materials and methods: The study included 1214 people. All of them were divided into two groups. Subgroups were identified in each group, depending on the presence of a particular clinical and biological variant of premature aging. All patients included in the study underwent cognitive psychological testing. Results: The most risky options of premature aging are cardiac, cerebral, mitochondrial, menopausal (in women), andropausal (in men) and mixed variants of premature aging. Moreover, with increasing age, gender differences increase. In the 55-64-year-old age group with mitochondrial, andropausal, and mixed variants of premature aging, the cognitive vulnerability of men was higher than that of women. So, if in women in the 55-64-year-old age group with the mitochondrial variant in women, the MMSE test score was $28.2 \pm 0.08$ points, then in men $-24.4 \pm 0.07(\mathrm{p}<0.05)$. In the menopausal variant, the MMSE test score was $27.1 \pm 0.04$ points, in the andropausal variant in men $-24.2 \pm 0.03(p<0.05)$. In the mixed variant, the MMSE test score for women was $25.1 \pm 0.16$ points, while for men it was $23.2 \pm 0.16(\mathrm{p}<0.05)$. Conclusion: 55-64-year-old men and women are most susceptible to cognitive and psychological vulnerability in mitochondrial, menopausal (in women), andropausal (in men) and mixed variants of premature aging, and being a male further increases this vulnerability.
\end{abstract}

Keywords: frailty; intrinsic capacity; resilience; premature aging

For citation: Malyutina ES, Fesenko EV, Sanches EA, et al. Influence of clinical and biological variants of premature aging on cognitive functionality. Research Results in Biomedicine. 2021;7(2):164-172. DOI: 10.18413/2658-6533-2021-7-2-0-7 
Introduction. Currently, the development of gerontology as a related medical and biological discipline follows the path of concepts; there are three of them in classical gerontology: frailty, intrinsic capacity and resilience, and in preventive gerontology there is one concept (premature aging) [1,2]. Frailty syndrome (FS) is a manifestation of various diseases against the background of age-related changes that manifests itself in the form of increased vulnerability of the body to various factors of the internal and external environment with the rapid development of adverse outcomes for health and quality of life [3, 4]. Intrinsic capacity (IC) is the totality of all physical and mental abilities of a person, which is divided into five domains: ability to move, sensory abilities (vision and hearing), vitality (energy level and balance), cognitive ability and psychological characteristics. Usually the concept of the environment, in which a person lives, is considered together with the IC, it includes such positions as devices and technologies that improve movement, sensory abilities that leads to an increase in the quality of life; natural and artificial living environment; emotional support and help from other people, communication with animals; relationships with other people; the presence/absence of special services that work with the elderly $[5,6]$. At the junction of the environment and IC there is an elderly person's functional ability or functionality. Achieving good functionality through geriatric interventions and work in order to improve the environment is the main goal of modern gerontology and geriatrics [7, 8, 9]. Resilience is a new concept that has been studied actively in recent years. There are physical and psychological types of it. Resilience is an elderly person's ability to cope with stress, both physical (for example, a sudden increase or decrease in the level of physical activity) and psychological (retirement, loss of loved ones, etc.). Polypragmasia or taking drugs in high doses is also considered a stress factor, this is especially important in the treatment of severe coronavirus infection, when it is necessary to prescribe high doses of glucocorticosteroids to interrupt excessive immune activation, which can lead to post-COVID syndrome with hypertensive reactions, if the patient's resilience is low. The formation of resilience is based on a complex of factors, such as genetic and immune ones, the state of the intestinal microbiota, as well as the level of stress hormones, etc. Resilience manages a quartet of factors including resilience-diet, resiliencegymnastics, resilience-psychology and resistance-drugs, which contribute to the strengthening of the physiological reserve and optimize the response to various stressful factors $[10,11]$.

In gerontoprophylaxis the concept of premature aging (PA), which is characterized by dissociation between chronological and biological age, which in the biological sense contributes to the abnormalities of various functional and anatomical systems of a person (PA by cardiac, cerebral, osteodynapenic, immune, metabolic and other types), is the most developed [12]. However, despite the widespread use of the term PA, this concept has not still been considered from the point of view of prevention and rehabilitation. At the same time, insufficient attention is paid to cognitive and psychological functionality, which is largely the basis for the formation of resilience $[13,14]$.

The aim of the research is to study the features of cognitive functioning of people with various clinical and biological variants of premature aging.

Materials and methods. The study included 1214 people. All of them were divided into two groups. The first group included 598 people in the age from 45 to 54, 292 men and 306 women, the average age was $49.2 \pm 1.8$. Subgroups were identified in each group, depending on the presence of a particular clinical and biological variant of premature aging. We distinguished cardiac, cerebral, ostedinapenic, mitochondrial, menopausal (in women), andropausal (in men), immune and mixed variants of premature aging (Table 1).

The following criteria were used to diagnose the variants of premature aging [8]. The cardiac variant of premature aging occurred, if the patient was diagnosed with arterial hypertension and/or clinical manifestations of atherosclerosis and/or chronic heart failure; if there were no such diseases a com- 
bination of two of the following signs occurred: high-normal blood pressure; dyslipidemia with an off-centre towards the predominance of proatherogenic cholesterol fractions; reduced volume of aerobic (motor) physical activity (less than 150 minutes per week); nicotine addiction; deformed or tired morphotype of skin aging.

Table 1

Characteristics of the patients included in the study

\begin{tabular}{|l|c|c|c|c|c|c|}
\hline \multicolumn{1}{c|}{$\begin{array}{c}\text { Variant of premature } \\
\text { aging }\end{array}$} & \multicolumn{3}{c|}{ Age 45-54 } & \multicolumn{3}{c|}{ Age 55-64 } \\
\cline { 2 - 7 } & Women & Men & Total & Women & Men & Total \\
\hline No premature aging & 37 & 38 & 75 & 33 & 37 & 70 \\
\hline Cardiac & 35 & 39 & 74 & 35 & 40 & 75 \\
\hline Cerebral & 33 & 38 & 71 & 38 & 41 & 79 \\
\hline Ostedinapenic & 34 & 35 & 69 & 42 & 36 & 78 \\
\hline Mitochondrial & 41 & 47 & 88 & 46 & 47 & 93 \\
\hline Menopausal & 38 & - & 38 & 45 & & 45 \\
\hline Andropausal & - & 35 & 35 & & 41 & 41 \\
\hline Immune & 39 & 40 & 79 & 31 & 32 & 63 \\
\hline Mixed & 35 & 34 & 69 & 39 & 33 & 72 \\
\hline Total & 292 & 306 & 598 & 309 & 307 & 616 \\
\hline
\end{tabular}

The cerebral variant of premature aging was determined at the level of cognitive abilities of 27 points or less according to the Minimental Scale Examination (MMSE); or at the level of cognitive abilities of 28-30 points according to MMSE with a combination of three of the following signs: chronic information exhaustion syndrome; proven sleep disorders; psychoemotional background reduced to the level of subdepression and/or depression; reduced volume of aerobic (motor) physical activity (less than 150 minutes per week); dysmorphomania (dysmorphophobia); microbiota disorders; deformative, fine-wrinkled or tired morphotype of skin aging. The criteria for the osteodynapenic variant of premature aging were: osteoporosis and/or sarcopenia and/or osteoarthritis of the joints of the lower limbs; or a combination of two of the following signs: osteopenia (proven by densitometry); dinapenia (proven by hand dynamometry); reduced volume of aerobic (motor) physical activity (less than 150 minutes per week); reduced frequency and volume of anaerobic (strength-building) physical activity (less than 2 times a week for less than 30 minutes each workout); tired or fine wrinkled morphotype of skin aging. The mitochondrial variant of premature aging was determined when the patient was obese or overweight with one of the following signs, and with normal or reduced body weight - with two of the following signs: high normal blood pressure or arterial hypertension; dyslipidemia or clinical manifestations of ath- erosclerosis; non-alcoholic steatohepatitis; the content of glycated hemoglobin in the blood serum is higher than $6.0 \%$; deformational or tired morphotype of skin aging. The immune variant of premature aging was determined when the patient was assigned to the group of frequently and long-term patients with acute respiratory viral infections (if there was ARVI more than four times a year for more than one week, while COVID-19 was not taken into account) in combination with one of the following signs: the volume of aerobic physical activity less than 150 minutes per week; reduced or excessive body weight; absolute zinc deficiency (confirmed by laboratory tests of blood serum); reduced vitamin D levels in blood serum; chronic infections of the skin and its appendages; a long rehabilitation period after socalled aggressive cosmetic procedures/manipulations. The menopausal variant of premature aging was a cardiac, cerebral, osteodynapenic or mitochondrial variant of premature aging in women in combination with menopause with pathological clinical manifestations. The andropausal variant of premature aging was a cardiac, cerebral, osteodynapenic or mitochondrial variant of premature aging in men in combination with agerelated androgen deficiency confirmed by laboratory tests. When conducting a comparative analysis, the menopausal variant of women's premature aging and the andropausal variant of men's premature aging were regarded as co-comparable. 
All patients included in the study underwent cognitive psychological testing. The level of cognitive abilities was determined with the use of the Mini-Mental State Examination (MMSE). To assess the emotional sphere, the Beck Depression Inventory was used. Sleep quality was determined by a 10point reverse Visual Analogue Scale (VAS) of sleep quality.

All the results were mathematically and statistically processed.

Results. The analysis of cognitive abilities showed that women in the 45-54 age group had a statistically significant $(\mathrm{p}<0.05)$ decrease in cognitive functionality in case of the cerebral variant of premature aging to $26.0 \pm 0.03$ points on the MMSE scale and in case of the mixed variant of premature aging to $25.0 \pm 0.14$ points compared to the level of $29.2 \pm 0.03$ points in the subgroup of women of the corresponding age without any signs of premature aging. Women in the 45-54 age group had a statistically significant $(\mathrm{p}<0.05)$ decrease in cognitive functionality in case of the cerebral variant of premature aging - up to $25.9 \pm 0.04$ points on the MMSE scale, in case of the menopausal variant of premature aging - up to $27.1 \pm 0.04$ points, in case of the mixed variant of premature aging - up to $25.1 \pm 0.16$ points, compared with the level of $29.0 \pm 0.04$ points in the subgroup of women of the corresponding age without signs of premature aging; while in the 55-64 age group with the menopausal variant, the index of cognitive functioning was significantly lower $(p<0.05)$ than in the similar variant of premature aging at the age of 45-54.

Moreover, women in the 45-54 age group had a statistically significant $(\mathrm{p}<0.05)$ deterioration in the indicators of psychological functioning, namely, there was an increase in the levels of depression according to the Beck scale in case of the cardiac variant of premature aging up to $15.4 \pm 1.8$ points, in case of the cerebral variant of premature aging up to $15.2 \pm 1.9$ points, in case of the osteodynapenic variant of premature aging - up to $14.8 \pm 2.3$ points, in case of the mitochondrial variant of premature aging - up to $20.4 \pm 1.6$ points, in case of the menopausal variant of premature aging - up to $20.1 \pm 1.1$ points, in case of the immune variant of premature ag- ing - up to $14.6 \pm 1.5$ points, in case of the mixed variant of premature aging - up to $15.2 \pm 1.4$ points, compared with the level of $3.3 \pm 0.2$ points in the subgroup of women of the corresponding age without signs of premature aging. At the same time, the level of depression in case of the mitochondrial and menopausal variants of premature aging was significantly higher $(p<0.05)$ than in case of other variants of premature aging.

Women in the 55-64 age group also had a statistically significant $(\mathrm{p}<0.05)$ deterioration in the indicators of psychological functioning, namely, there was an increase in the levels of depression according to the Beck scale in case of the cardiac variant of premature aging - up to $15.2 \pm 1.4$ points, in case of the cerebral variant of premature aging - up to $14.9 \pm 2.2$ points, in case of the osteodynapenic variant of premature aging - up to $14.9 \pm 1.8$ points, in the mitochondrial variant of premature aging - up to $16.4 \pm 1.2$ points, in case of the menopausal variant of premature aging - up to $15.0 \pm 1.4$ points, in case of the immune variant of premature aging - up to $15.7 \pm 0.6$ points, in case of the mixed variant of premature aging - up to $20.2 \pm 1.7$ points, compared with the level of $3.5 \pm 0.5$ points in the subgroup of women of the corresponding age without any signs of premature aging. At the same time, the level of depression in case of the mixed variants of premature aging was significantly higher $(p<0.05)$ than in other variants of premature aging in this age group. It was interesting that in contrast to the 45-54 age group, in the 55-64 age group there was no critical decrease in the indicators of psychological functioning in case of the metabolic and mitochondrial variants of premature aging compared to other variants of premature aging.

When assessing the quality of sleep using a 10-point inverse VAS of sleep quality, it was found out that in the 45-54 age group women with most variants of premature aging had a statistically significant $(p<0.05)$ deterioration of the indicators: in case of the cardiac variant of premature aging - up to $6.3 \pm 0.7$ points, in case of the cerebral variant of premature aging - up to $6.0 \pm 0.6$ points, in case of the mitochondrial variant of premature aging - up to $6.2 \pm 1.2$ points, in case of the menopausal variant of premature aging - up to $6.7 \pm 1.1$ points, in case of the mixed variant of premature aging - up to 
$6.9 \pm 1.2$ points compared to the level of $1.1 \pm 0.2$ points in the subgroup of women of the corresponding age without any signs of premature aging. At the same time, no such changes were detected in case of the osteodynapenic and immune variants of premature aging.

In the 55-64 age group, women with all (except immune) variants of premature aging had a statistically significant $(\mathrm{p}<0.05)$ deterioration in sleep quality indicators: in case of the cardiac variant of premature aging - up to $6.8 \pm 2.1$ points, in case of the cerebral variant of premature aging - up to $6.5 \pm 2.4$ points, in case of the osteodynapenic variant of premature aging - up to $5.7 \pm 2.2$ points, in case of the mitochondrial variant of premature aging - up to $6.4 \pm 2.0$ points, in case of the menopausal variant of premature aging - up to $8.9 \pm 0.3$ points, in case of the mixed variant of premature aging - up to $6.0 \pm 1.2$ points compared to the level of $1.4 \pm 0.3$ points in the subgroup of women of the corresponding age without any signs of premature aging. At the same time, in the 55-64 age group with the menopausal variant, sleep quality indicators were significantly worse $(p<0.05)$ than in case of the similar variant of premature aging at the age of 45-54 (Table 2).

Changes in the indicators of cognitive and psychological functioning, as well as the quality of sleep in men, followed the same patterns as in women (Table 3).

Table 2

Functioning of the cognitive-psychological sphere indicators in women with various variants of premature aging

\begin{tabular}{|c|c|c|c|c|c|c|}
\hline \multirow[b]{2}{*}{$\begin{array}{c}\text { Variant of premature } \\
\text { aging }\end{array}$} & \multicolumn{3}{|c|}{ Women, $45-54$ years of age } & \multicolumn{3}{|c|}{ Women, 55-64 years of age } \\
\hline & MMSE & Beck scale & $\begin{array}{c}\text { Inverse } \\
\text { VAS } \\
\text { of sleep }\end{array}$ & MMSE & Beck scale & $\begin{array}{c}\text { Inverse } \\
\text { VAS } \\
\text { of sleep }\end{array}$ \\
\hline No premature aging & $29.2 \pm 0.03$ & $3.3 \pm 0.2$ & $1.1 \pm 0.2$ & $29.0 \pm 0.04$ & $3.5 \pm 0.5$ & $1.4 \pm 0.3$ \\
\hline Cardiac & $28.9 \pm 0.07$ & $15.4 \pm 1.8^{*}$ & $6.3 \pm 0.7^{*}$ & $28.8 \pm 0.03$ & $15.2 \pm 1.4^{*}$ & $6.8 \pm 2.1^{*}$ \\
\hline Cerebral & $26.0 \pm 0.03^{* * *}$ & $15.2 \pm 1.9^{*}$ & $6.0 \pm 0.6^{*}$ & $25.9 \pm 0.04^{* * *}$ & $14.9 \pm 2.2^{*}$ & $6.5 \pm 2.4^{*}$ \\
\hline Ostedinapenic & $29.7 \pm 0.02$ & $14.8 \pm 2.3^{*}$ & $1.5 \pm 0.3$ & $29.5 \pm 0.03$ & $14.9 \pm 1.8^{*}$ & $5.7 \pm 2.2^{\# *}$ \\
\hline Mitochondrial & $28.4 \pm 0.12$ & $20.4 \pm 1.6^{*},{ }^{\circ}$ & $6.2 \pm 1.1^{*}$ & $28.2 \pm 0.08$ & $16.4 \pm 1.2^{*}$, & $6.4 \pm 2.0^{*}$ \\
\hline Menopausal & $28.8 \pm 0.02$ & $20.1 \pm 1.1^{*, 0}$ & $6.7 \pm 1.2^{*}$ & $27.1 \pm 0.04^{*}$, & $15.0 \pm 1.4^{*}, \#$ & $8.9 \pm 0.3^{*}, \mathrm{o \#}$ \\
\hline Immune & $29.0 \pm 0.06$ & $14.6 \pm 1.5^{*}$ & $2.2 \pm 0.8$ & $29.3 \pm 0.05$ & $15.7 \pm 0.6^{*}$ & $2.4 \pm 0.5$ \\
\hline Mixed & $25.0 \pm 0.14^{* * *}$ & $15.2 \pm 1.4^{*}$ & $6.9 \pm 2.1^{*}$ & $25.1 \pm 0.16^{* * *}$ & $20.2 \pm 1.7^{*}$, o \# & $6.0 \pm 1.2^{*}$ \\
\hline
\end{tabular}

Note: ${ }^{*} \mathrm{p}<0.05$ compared to the subgroup with no premature aging, ${ }^{* *} \mathrm{p}<0.05$ compared to the subgroups with cardiac, cerebral, osteodynapenic, menopausal and immune variants of premature aging, ${ }^{{ }^{*}} \mathrm{p}<0.05$ compared to people aged $45-54,{ }^{\circ} \mathrm{p}<0.05$ compared to other variants of premature aging.

Table 3

Functioning of the cognitive-psychological sphere indicators in men with various variants of premature aging

\begin{tabular}{|c|c|c|c|c|c|c|}
\hline \multirow[b]{2}{*}{$\begin{array}{c}\text { Variant of premature } \\
\text { aging }\end{array}$} & \multicolumn{3}{|c|}{ Men, $45-54$ years of age } & \multicolumn{3}{|c|}{ Men, 55-64 years of age } \\
\hline & MMSE & Beck scale & $\begin{array}{c}\text { Inverse } \\
\text { VAS } \\
\text { of sleep }\end{array}$ & MMSE & Beck scale & $\begin{array}{c}\text { Inverse } \\
\text { VAS } \\
\text { of sleep }\end{array}$ \\
\hline No premature aging & $29.1 \pm 0.04$ & $3.1 \pm 0.3$ & $1.0 \pm 0.1$ & $29.1 \pm 0.08$ & $3.4 \pm 0.7$ & $1.2 \pm 0.3$ \\
\hline Cardiac & $28.7 \pm 0.05$ & $15.1 \pm 1.7^{*}$ & $6.4 \pm 0.6^{*}$ & $28.7 \pm 0.02$ & $14.8 \pm 1.9^{*}$ & $6.7 \pm 1.8^{*}$ \\
\hline Cerebral & $26.1 \pm 0.02^{* * *}$ & $14.3 \pm 1.5^{*}$ & $6.1 \pm 0.5^{*}$ & $25.6 \pm 0.06^{*}$ & $14.8 \pm 2.3^{*}$ & $6.5 \pm 1.3^{*}$ \\
\hline Ostedinapenic & $29.6 \pm 0.01$ & $13.7 \pm 1.6^{*}$ & $1.4 \pm 0.1$ & $29.4 \pm 0.05$ & $14.5 \pm 1.6^{*}$ & $5.1 \pm 1.1^{\# *}$ \\
\hline Mitochondrial & $28.6 \pm 0.14$ & $19.2 \pm 2.2^{*}$, & $6.3 \pm 1.0^{*}$ & $24.4 \pm 0.07$ & $16.6 \pm 1.3^{*}$, & $6.5 \pm 1.4^{*}$ \\
\hline Andropausal & $28.6 \pm 0.04$ & $20.2 \pm 1.3^{*}$. & $6.5 \pm 1.3^{*}$ & $24.2 \pm 0.03^{\#}$ & $14.8 \pm 2.1^{* \#}$ & $8.8 \pm 0.4^{*}, \mathrm{o \#}$ \\
\hline Immune & $29.2 \pm 0.07$ & $15.1 \pm 1.6^{*}$ & $2.1 \pm 0.9$ & $28.9 \pm 0.11$ & $15.8 \pm 0.5^{*}$ & $2.2 \pm 0.2$ \\
\hline Mixed & $25.1 \pm 0.12^{* * *}$ & $16.0 \pm 1.5^{*}$ & $6.6 \pm 1.4^{*}$ & $23.2 \pm 0.16^{* * *}$, & $20.1 \pm 2.1^{*}, \mathrm{o}$, & $6.1 \pm 0.7^{*}$ \\
\hline
\end{tabular}

Note: ${ }^{*} \mathrm{p}<0.05$ compared to the subgroup with no premature aging, ${ }^{* *} \mathrm{p}<0.05$ compared to subgroups with cardiac, cerebral, osteodynapenic, andropausal, and immune variants of premature aging, ${ }^{* *} \mathrm{p}<0.05$ compared to people aged $45-54$, ${ }^{o} \mathrm{p}<0.05$ compared to other variants of premature aging. 
Discussion. In terms of the risks of cognitive and psychological vulnerability mitochondrial, cerebral, menopausal (in women) and andropausal (in men) variants of premature aging should be considered as the most unfavorable ones $[14,15]$. However, at the age of 45-54 gender does not have a significant role in increasing risks, though, when age increases, gender differences also increase. It should be noted that in the 55-64 age group with mitochondrial, andropausal and mixed variants of premature aging, the cognitive vulnerability of men was higher than that of women. Thus, in the 55-64 age group of women with the mitochondrial variant the MMSE test score was $28.2 \pm 0.08$ points, while in men's group $-24.4 \pm 0.07(p<0.05)$. In case of the menopausal variant the MMSE test score was $27.1 \pm 0.04$ points, in case of men's andropausal variant $-24.2 \pm 0.03(\mathrm{p}<0.05)$. In case of the mixed variant the MMSE test score was $25.1 \pm 0.16$ points for women, while it was $23.2 \pm 0.16(p<0.05)$ for men $[16,17]$.

Such patterns are potentially associated with two factors. The first group of factors is associated with the formation of a metabolic cardiovascular continuum that combines the processes of mitochondrial dysfunction, blood pressure dysregulation and endothelial dysfunction with their targeting in regard to brain tissue. The second group of reasons is associated with the peculiarities of hormonal metabolism and a more significant effect on the cognitive sphere of age-related androgen deficiency in comparison with menopausal changes in women $[18,19,20]$.

Thus, premature aging in both women and men is a risk factor for reduced cognitive and psychological functionality. The riskiest options are cardiac, cerebral, mitochondrial, menopausal (in women), andropausal (in men) and mixed variants of premature aging.

Conclusion. 55-64-year-old men and women are most susceptible to cognitive and psychological vulnerability in case of mitochondrial, menopausal (in women), andropausal (in men) and mixed variants of premature aging. Besides, being a male increases this vulnerability. Patients with mitochondrial, menopausal (in women), andropausal (in men) variants of premature aging should be considered as a group of additional targeted effects when planning preventive and rehabilitative measures.

\section{Информация о финансировании}

Финансирование данной работы не проводилось.

\section{Financial support}

No financial support has been provided for this work.

\section{Конфликт интересов}

Авторы заявляют об отсутствии конфликта интересов.

\section{Conflict of interests}

The authors have no conflict of interest to declare.

\section{Список литературы}

1. Prina M, Moreno-Agostino D, Co $\mathrm{M}$ et al. WHO recommendations on primary prevention interventions to improve intrinsic capacity across the life-course: a systematic review. Background paper prepared for WHO Consortium on Metrics and Evidence for Healthy Ageing, Geneva, 10-11 October 2019. Geneva: World Health Organization; 2019.

2. World Health Organization. Decade of healthy ageing: baseline report [Internet]. 2021 [cited 2021 Apr 21]. Available from: https://www.who.int/publications/i/item/97892400 17900

3. Ткачева ОН, Котовская ЮВ, Остапенко ВС, и др. Особенности клинических подходов к ведению пациентов со старческой астенией. РМЖ. 2017;25:1823-1825.

4. Belloni G, Cesari M. Frailty and Intrinsic Capacity: Two Distinct but Related Constructs. Frontiers in Medicine. 2019;6:133. DOI: https://doi.org/10.3389/fmed.2019.00133

5. Fontes AP, Neri AL. Resilience in aging: literature review. Ciencia e Saude Coletiva. 2015;20(5):1475-95.

DOI: https://doi.org/10.1590/141381232015205.00502014

6. Cesari M, de Carvalho IA, Thiyagarajan JA, et al. Evidence for the Domains Supporting the Construct of Intrinsic Capacity. Journals of Gerontology - Series A Biological Sciences and Medical Sciences. 2018;73(12):1653-1660. DOI: https://doi.org/10.1093/gerona/gly011 
7. Орлова ОА, Линькова НС, Трофимова $\mathrm{CB}$, и др. Общие теории старения и частный случай: анализ старения кожи и достижения современной косметологии. Геронтология. 2017;5(1):10-30.

8. Прощаев КИ, Ильницкий АН, Галкина ИЮ, и др. Преждевременное старение и возрастная жизнеспособность. Геронтология. 2021;9(1):1-9.

9. Ильницкий АН, Прощаев КИ, Коршун ЕИ. Клеточные хроноблокаторы и старение головного мозга. Геронтология. 2017;5(1):104-112.

10.Nestola T, Orlandini L, Beard JR, et al. COVID-19 and Intrinsic Capacity. Journal of Nutrition, Health and Aging. 2020;24(7):692-695. DOI: https://doi.org/10.1007/s12603-020-1397-1

11.Позднякова НM, Логвинова НВ. Преждевременное старение как медикосоциальная проблема [Электронный ресурс]. Современные проблемы науки и образования. 2012 [дата обращения 21.04.2021];6. URL: https://www.science-

education.ru/ru/article/view?id=7786

12.Beard JR, Jotheeswaran AT, Cesari M, et al. The structure and predictive value of intrinsic capacity in a longitudinal study of ageing. BMJ Open. 2019;9(11):e026119. DOI: https://doi.org/10.1136/bmjopen-2018-026119

13.Шарова АА. Особенности гериатрического статуса, определяющие направления геронтологической профилактики пациентов разного возраста в клиниках эстетической медицины. Научные результаты биомедицинских исследований. 2020;6(4):561-572. DOI: https://doi.org/10.18413/2658-6533-2020-6-4-011

14.Пономаренко ИВ, Прощаев КИ, Шагинян ГГ, и др. «Рисковые» комбинации генов-кандидатов гиперпластических процессов эндометрия. Молекулярная медицина. 2018;16(2):61-64. DOI: https://doi.org/10.29296/24999490-2018-02-09

15. Maki PM, Thurston RC. Menopause and Brain Health: Hormonal Changes Are Only Part of the Story. Frontiers in Neurology. 2020;11:562275. DOI: https://doi.org/10.3389/fneur.2020.562275

16. Barrientos BG, Llanos VP, BasualtoAlarcón C, et al. Androgen-regulated cardiac metabolism in aging men. Frontiers in Endocrinolo- gy. 2020;11:316. DOI: https://doi.org/10.3389/fendo.2020.00316

17. Kirlangic OF, Yilmaz-Oral D, KayaSezginer E, et al. The Effects of Androgens on Cardiometabolic Syndrome: Current Therapeutic Concepts. Sexual Medicine. 2020;8(2):132-155. DOI: https://doi.org/10.1016/j.esxm.2020.02.006

18.Жабоева С.Л., Полев А.В. Клиническая актуальность программ геронтологической профилактики: современный взгляд на проблему. Геронтология. 2020 [дата обращения 21.04.2021]; 2. URL: http://www.gerontology.su/magazines?text=338

19. Kaufman JM, Lapauw B. Role of testosterone in cognition and mobility of aging men. Andrology. 2020;8(6):1567-1579. DOI: https://doi.org/10.1111/andr.12872

20.Desdín-Micó G, Soto-Heredero G, Aranda JF, et al. $\mathrm{T}$ cells with dysfunctional mitochondria induce multimorbidity and premature senescence. Science. 2020;368(6497):1371-1376. DOI: https://doi.org/10.1126/science.aax0860

\section{References}

1. Prina M, Moreno-Agostino D, Co $\mathrm{M}$ et al. WHO recommendations on primary prevention interventions to improve intrinsic capacity across the life-course: a systematic review. Background paper prepared for WHO Consortium on Metrics and Evidence for Healthy Ageing, Geneva, 10-11 October 2019. Geneva: World Health Organization; 2019.

2. World Health Organization. Decade of healthy ageing: baseline report [Internet]. 2021 [cited 2021 Apr 21]. Available from: https://www.who.int/publications/i/item/97892400 17900

3. Tkacheva ON, Kotovskaya YuV, Ostapenko VS, et al. Features of clinical approaches to managing patients with senile asthenia. Russian Medical Journal. 2017;25:1823-1825. Russian.

4. Belloni G, Cesari M. Frailty and Intrinsic Capacity: Two Distinct but Related Constructs. Frontiers in Medicine. 2019;6:133. DOI: https://doi.org/10.3389/fmed.2019.00133

5. Fontes AP, Neri AL. Resilience in aging: literature review. Ciencia e Saude Coletiva. 2015;20(5):1475-95. DOI: https://doi.org/10.1590/141381232015205.00502014 
6. Cesari M, de Carvalho IA, Thiyagarajan JA, et al. Evidence for the Domains Supporting the Construct of Intrinsic Capacity. Journals of Gerontology - Series A Biological Sciences and Medical Sciences. 2018;73(12):1653-1660. DOI: https://doi.org/10.1093/gerona/gly011

7. Orlova OA, Linkova NS, Trofimova SV, et al. Total theories of ageing and particular case: the analysis of skin ageing and progress of modern cosmetology. Gerontology. 2017;5(1):10-30. Russian.

8. Prashchayeu KI, Ilnitsky AN, Galkina $\mathrm{IYu}$, et al. Premature aging and resilience. Gerontology. 2021;9(1):1-9. Russian.

9. Ilnitskii AN, Prashchayeu KI, Korshun EI. Cellular chrono blockers and brain aging. Gerontology. 2017;5(1):104-112. Russian

10.Nestola T, Orlandini L, Beard JR, et al. COVID-19 and Intrinsic Capacity. Journal of Nutrition, Health and Aging. 2020;24(7):692-695. DOI: https://doi.org/10.1007/s12603-020-1397-1

11.Pozdnyakova NM, Logvinova NV. Premature aging as a medical and social problem [Internet]. Modern problems of science and education. 2012 [cited 2021 Apr 21];6. Russian. Available from: https://www.scienceeducation.ru/ru/article/view?id=7786

12.Beard JR, Jotheeswaran AT, Cesari M, et al. The structure and predictive value of intrinsic capacity in a longitudinal study of ageing. BMJ Open. 2019;9(11):e026119. DOI: https://doi.org/10.1136/bmjopen-2018-026119

13. Sharova AA. Features of the geriatric status guiding gerontological prevention of patients of different ages in aesthetic medicine clinics. Research Results in Biomedicine. 2020;6(4):561-572. Russian. DOI: https://doi.org/10.18413/2658-65332020-6-4-0-11

14.Ponomarenko IV, Prashchayeu KJ, Shaginyan GG, et al. "Risky" combinations of candidate genes for hyperplastic processes of the endometrium. Molecular Medicine. 2018;16(2):61-64. Russian. DOI: https://doi.org/10.29296/24999490-2018-02-09

15.Maki PM, Thurston RC. Menopause and Brain Health: Hormonal Changes Are Only Part of the Story. Frontiers in Neurology. 2020;11:562275. DOI: https://doi.org/10.3389/fneur.2020.562275

16. Barrientos BG, Llanos VP, BasualtoAlarcón C, et al. Androgen-regulated cardiac metabolism in aging men. Frontiers in Endocrinolo- gy. 2020;11:316. DOI: https://doi.org/10.3389/fendo.2020.00316

17. Kirlangic OF, Yilmaz-Oral D, KayaSezginer E, et al. The Effects of Androgens on Cardiometabolic Syndrome: Current Therapeutic Concepts. Sexual Medicine. 2020;8(2):132-155. DOI: https://doi.org/10.1016/j.esxm.2020.02.006

18.Zhaboeva S.L., Polev A.V. Clinical relevance of gerontological prevention programs: a modern view of the problem. Gerontology. 2020 [cited 2021 Apr 21];2. Russian. Available from: URL:

http://www.gerontology.su/magazines?text=338

19. Kaufman JM, Lapauw B. Role of testosterone in cognition and mobility of aging men. Andrology. 2020;8(6):1567-1579. DOI: https://doi.org/10.1111/andr.12872

20.Desdín-Micó G, Soto-Heredero G, Aranda JF, et al. $\mathrm{T}$ cells with dysfunctional mitochondria induce multimorbidity and premature senescence. Science. 2020;368(6497):1371-1376. DOI: https://doi.org/10.1126/science.aax0860

Received 3 March 2021

Revised 21 April 2021

Accepted 11 May 2021

\section{Information about the authors}

Elena S. Malyutina, Cand. Sci. (Medicine), Associate Professor at the Department of Pathology, Belgorod State National Research University, Belgorod, Russia, E-mail: malyutina_elena@list.ru, ORCID: https://orcid.org/00000002-7065-7548.

Elvira V. Fesenko, Cand. Sci. (Medicine), Associate Professor at the Department of Internal Diseases, Geriatrics and Anti-aging Medicine, Academy of Postgraduate Education, Federal Scientific and Clinical Center for Specialized Medical Assistance and Medical Technologies, Federal Medical Biological Agency, Moscow, Russia, E-mail: longtermcare.fmba@gmail.com, ORCID https://orcid.org/0000-0003-2187-5060.

Elena A. Sanches, Cand. Sci. (Medicine), Associate Professor at the Department of Dermatovenereology and Cosmetology, Academy of Postgraduate Education, Federal Scientific and Clinical Center for Specialized Medical Assistance and Medical Technologies, Federal Medical Biological Agency, Moscow, Russia, E-mail: elena.sanches@gmail.com, ORCID ID: https://orcid.org/0000-0001-7931-4253. 
Viktoriya D. Ismanova, Post-graduate Student in scientific specialty 14.01.30 - Gerontology and Geriatrics, Academy of Postgraduate Education, Federal Scientific and Clinical Center for Specialized Medical Assistance and Medical Technologies, Federal Medical Biological Agency, Moscow, Russia, E-mail: ismanova_vika@mail.ru, https://orcid.org/0000-0001-7474-8212.

Oleg M. Kuzminov, Cand. Sci. (Medicine), Associate Professor, Associate Professor at the Department of Propedeutics of Internal Medicine and Clinical Information Technologies, Belgorod State National Research University, Belgorod, Russia, E-mail: malyutina_elena@list.ru, E-mail: kuzminov@bsu.edu.ru, ORCID: https://orcid.org/0000-0001-7086-9420. 